\title{
Effect of Indole-3-Acetic Acid (IAA) on Biochemical Responses of Cowpea (Vigna unguiculata (L.) Walp) Var. Bari Fellon-1
}

\author{
K. Taslima ${ }^{a^{*}}$, F. Hossain ${ }^{a}$ and U. Ara ${ }^{b}$ \\ ${ }^{a}$ Department of Botany, Jahangirnagar University, Savar, Dhaka-1342, Bangladesh and \\ ${ }^{b}$ Institute of Food Science \& Technology Bangladesh Council of Scientific and \\ Industrial Research, Dhaka, Bangladesh
}

\begin{abstract}
The biochemical responses of Cowpea to IAA treatments (foliar spray) with different concentrations (20 ppm, 40 ppm, $60 \mathrm{ppm}$ and $80 \mathrm{ppm}$ ) were studied. Biochemical parameters such as leaf pigments, moisture, ash, crude fiber, calorie, protein, fat, carbohydrate and nitrogen free extract (NFE) contents in seeds of Cowpea were studied in the experiment. Different biochemical parameters responded differently following IAA treatments. Highest protein content $(22.7 \%)$ and ash content $(4.2 \%)$ were recorded from the seeds of the plants treated with 80 ppm IAA. Highest carbohydrate content (60.8\%) and calorie content were recorded from the seeds of the plants treated with 60 ppm IAA. Moisture content was decreased due to all IAA treatments. Fat, crude fiber and NFE content of seeds also found to be varied with different treatments. Out of all the treatments, the best stimulation was found for $60 \mathrm{ppm}$ IAA treatment. The results of the present work also indicate that an appropriate concentration of IAA can be fruitfully utilized to produce better quality of seeds and leaf pigments of Cowpea.
\end{abstract}

Key words: Auxins, Biochemical response, IAA treatment, Cowpea

\section{Introduction}

Auxins play a major role in plant growth and development. They are either natural or synthetic compounds and can be applied directly to plants in various ways to alter life processes and structure or both in some beneficial way, so as to improve quality or to facilitate harvesting. Among the auxins indole-3-acetic acid (IAA) is the first known natural ubiquitous auxin in plants (Davies 2004). IAA has been implicated in a wide range of developmental processes, some of them include elongation growth, photo-and gravitropism, apical dominance, lateral root initiation, the differentiation of vascular tissues, embryogenesis, fruit setting and ripening and senescence (Macdonald 1997).

Grain legumes occupy an important position in the world agriculture by virtue of their high vegetable protein content, wide acceptance as part of the human diet, low cost of production, capacity for fixing atmospheric nitrogen and their easy and safe transportability. The problems of protein malnutrition in the developing countries of the world can be solved by increasing the production of grain legumes (Kharkwal et al. 1986). Pulses are considered as poor man's meat since they are the cheapest source of protein for the underprivileged people who cannot afford animal proteins. Cereals contain on an average $5-18 \%$ crude protein, while pulses contain 11 to $40 \%$, which is nearly three times the quantity found in cereals (Gowda and Kaul 1982). Moreover, Pulses are rich in minerals such as calcium and iron and are also rich in vitamin A and D (Gowda and Kaul 1982) and can provide all the $\mathrm{B}$ vitamins lost in polished rice. Cowpea (Vigna unguiculata (L.) Walp), a grain legume plant, is a protein source of the diet of many people has long been recognized by the International Institute of Tropical Agriculture (IITA). Rachie (1985) reported that in some areas of the semi-humid tropics, Cowpea provides more than half the protein in human diet. Bangladesh is one of the most over populated country of the world having the lowest per capita arable land and traditional agriculture production system. So Cowpea was chosen for this study mainly because it fits well in the prevailing crop system and grows under low input conditions.

\footnotetext{
* Corresponding author: E-mail: k_taslima08@yahoo.com
} 
Reports so far has been made indicate a promising result on yield and quality of various crops due to use of growth regulators such as Dimethyl sulphoxide (DMSO), Gibberellic acid $\left(\mathrm{GA}_{3}\right)$, Indole-3-acetic acid (IAA) etc. (Voronova 1983; Sentelhas et al. 1987; Tadzhiryan 1990 and Tomar et al. 1991). Effect of IAA on root elongation of the mung bean (Vigna radiate L. Wilczek) has been reported (Ali et al. 2008). The objective of the present investigation is an attempt to study the effect on biochemical changes of seed of Cowpea using different concentrations of IAA as well as to screen out the better concentration of IAA treatment.

\section{Materials and Methods}

The field experiment was conducted in the experimental field of Botanical garden of Botany Department, Jahangirnagar University, Savar, Dhaka, during the period from December, 2001 to April, 2002. Seeds of Cowpea were collected from Agricultural University, Shere-a-bangla nagar, Dhaka which were used as plant material. The field was prepared with proper precautions and divided into 15 plots of $\left(3.15 \mathrm{~m} \mathrm{x} 2.15 \mathrm{~m}=7.08 \mathrm{~m}^{2}\right)$ having footpaths of 20 $\mathrm{cm}$ in between. Experimental field block design is shown in Figure 1. After 40 days of emergence of the seedling a first spraying treatment was made and that was followed by second spraying after 15 days. Treatment schedule of IAA is given in Table I.. After the end of the field experiment, the biochemical analysis of the seeds of Cowpea were carried out at the plant physiology and biochemistry laboratory of Botany Department of Jahangirnagar University and partly

\begin{tabular}{l|c|c|c|c}
\hline $\mathrm{T}_{4}$ & $\mathrm{~T}_{3}$ & $\mathrm{~T}_{2}$ & $\mathrm{~T}_{1}$ & $\mathrm{~T}_{0}$ \\
\hline $\mathrm{T}_{3}$ & $\mathrm{~T}_{2}$ & $\mathrm{~T}_{0}$ & $\mathrm{~T}_{3}$ & $\mathrm{~T}_{4}$ \\
\hline $\mathrm{T}_{0}$ & $\mathrm{~T}_{1}$ & $\mathrm{~T}_{4}$ & $\mathrm{~T}_{2}$ & $\mathrm{~T}_{1}$ \\
\hline
\end{tabular}

* Notations are explained in Table I

Fig. 1: Block design of the experimental field

Table I: Treatment Schedule of IAA

\begin{tabular}{l|l}
\hline $\begin{array}{l}\text { Treatment } \\
\text { name }\end{array}$ & Treatment schedule \\
\hline $\mathrm{T}_{0}$ & Foliar application of distilled water (control) \\
$\mathrm{T}_{1}$ & Foliar application of 20 ppm IAA. \\
$\mathrm{T}_{2}$ & Foliar application of 40 ppm IAA. \\
$\mathrm{T}_{3}$ & Foliar application of 60 ppm IAA. \\
$\mathrm{T}_{4}$ & Foliar application of 80 ppm IAA. \\
\hline
\end{tabular}

in Bangladesh Council of Scientific and Industrial Research (BCSIR), Dhaka. Differently treated plants were separately harvested and seeds were collected from the plants for different parameters. Ten randomly selected plants were used from each treatment for collecting data.

Chlorophyll $\mathrm{a}$ and $\mathrm{b}$ content of leaves were determined for each treatment from the age of 15 days after spray (DAS) at an interval of 10 days up to 35 DAS using UV spectrophotometer (Spectronic Unicam, England) in BCSIR. Specific absorption co-efficient method of Mckinney (1940) and the formula of Machlachalan and Zalik (1963) were used to determine the amount of chlorophyll-a and Chlorophyll-b. Quantitative determination of ash, crude fibre, protein, fat and carbohydrate content of seeds were determined following AOAC (1985) protocol.

\section{Statistical analysis}

Data collected on different parameters were statistically analyzed and treatment means were compared by Least Significant Difference Test (LSD Test). The analysis of variance (ANOVA) was conducted following the procedure laid down by Gomez and Gomez (1984) to calculate the differences between the treatments. Data were also analyzed using SPS program (version 10.05).

\section{Results and Discussion}

\section{Chlorophyll-a and Chlorophyll-b}

Effect of different concentration of IAA on chlorophyll-a and chlorophyll-b content of leaves of Cowpea are presented in Table II. The results of the present investigation indicate that chlorophyll-a and b content of Cowpea leaves is increased due to all treatments at three different stages after the spray. The highest chlorophyll-a content was recorded from the leaf of plant treated with $\mathrm{T}_{3}$ treatment $(60 \mathrm{ppm}$ IAA) and it was $44.17 \%$ over that of the control. The lowest chlorophyll-a content $1.20 \mathrm{mg} / \mathrm{g}$ was recorded from the control. The percentage increase over the control was 7.5 to 44.2. The highest chlorophyll-b content was recorded from the leaf of plant treated with $\mathrm{T}_{4}$ treatment ( $80 \mathrm{ppm}$ IAA) and the lowest chlorophyll-b content was recorded from the control. The percentage increase over control ranged from 12.2 to 73.7. Similar results of increased chlorophyll content with IAA treatment have been reported by Shobha Johari et al. (1994) on Euphorbia antisyphilitica. Subramanian and 
Table II. Effect of different concentration of IAA on chlorophyll-a and chlorophyll-b content of leaves of Cowpea (results are in $\mathbf{m g} / \mathrm{g}$ )

\begin{tabular}{c|c|c|c|c|c|c}
\hline \multirow{2}{*}{ Treatments } & \multicolumn{6}{|c|}{ Days After Spray (DAS) } \\
\cline { 2 - 7 } & \multicolumn{2}{|c|}{15} & \multicolumn{2}{c}{25} & \multicolumn{2}{c}{35} \\
\cline { 2 - 7 } & Chlorophyll-a & Chlorophyll-b & Chlorophyll-a & Chlorophyll-b & Chlorophyll-a & Chlorophyll-b \\
\hline \multirow{2}{*}{$\mathrm{T}_{0}$} & $1.29 \mathrm{e}$ & $0.68 \mathrm{e}$ & $1.34 \mathrm{e}$ & $0.78 \mathrm{e}$ & $1.20 \mathrm{e}$ & $0.68 \mathrm{e}$ \\
$\mathrm{T}_{1}$ & $1.31 \mathrm{~d}$ & $0.78 \mathrm{c}$ & $1.38 \mathrm{~d}$ & $0.88 \mathrm{~d}$ & $1.29 \mathrm{~d}$ & $0.80 \mathrm{~d}$ \\
& $(1.55)$ & $(13.9)$ & $(2.99)$ & $(12.2)$ & $(7.5)$ & $(17.1)$ \\
$\mathrm{T}_{2}$ & $1.39 \mathrm{c}$ & $0.73 \mathrm{~d}$ & $1.52 \mathrm{c}$ & $0.89 \mathrm{c}$ & $1.49 \mathrm{c}$ & $0.83 \mathrm{c}$ \\
& $(7.75)$ & $(6.8)$ & $(13.4)$ & $(13.6)$ & $(24.17)$ & $(21.5)$ \\
$\mathrm{T}_{3}$ & $1.49 \mathrm{~b}$ & $0.85 \mathrm{~b}$ & $1.60 \mathrm{~b}$ & $0.95 \mathrm{~b}$ & $1.73 \mathrm{a}$ & $0.96 \mathrm{~b}$ \\
& $(15.5)$ & $(24.4)$ & $(19.4)$ & $(21.4)$ & $(44.17)$ & $(40.7)$ \\
$\mathrm{T}_{4}$ & $1.65 \mathrm{a}$ & $0.99 \mathrm{a}$ & $1.72 \mathrm{a}$ & $1.36 \mathrm{a}$ & $1.63 \mathrm{~b}$ & $0.99 \mathrm{a}$ \\
& $(27.9)$ & $(44.9)$ & $(28.4)$ & $(73.6)$ & $(35.8)$ & $(44.7)$ \\
$\mathrm{ANOVA}$ & $\mathrm{S}$ & $\mathrm{S}$ & $\mathrm{S}$ & $\mathrm{S}$ & $\mathrm{S}$ & $\mathrm{S}$ \\
CV (\%) & 0.63 & 0.01 & 0.63 & 0.56 & 0.03 & 0.07 \\
LSD (1\%) & 0.02 & 0.0003 & 0.03 & 0.015 & 0.01 & 0.0019 \\
LSD (5\%) & 0.02 & 0.0002 & 0.02 & 0.0103 & 0.01 & 0.0013 \\
\hline
\end{tabular}

$\mathrm{S}$ for significant; Average was taken over the values of 3 replicates.

Values within parentheses indicate percentage of change relative to the control $\left(\mathrm{T}_{0}\right)$.

Means in a column followed by the same letter do not differ significantly at $1 \%$ and $5 \%$ level.

Jahardhanan (1992) observed that the concentrations 72 $3 \mathrm{ml} /$ litre of cytozyme (a mixture of cytokinin, auxin, enzymes and trace elements) generally inhibited concentration of chlorophyll in cowpea cv. co. 3 , pigeon pea cv. co.5 and soyabean cv. col. 1 .

The estimation of chlorophyll pigments is of importance because increase in chlorophyll leads to the increase in production of photosynthate and as a result of more photosynthetic production and accumulation improved growth and development of plant occur and therefore improved growth and development lead to higher crop yield. The increase in chlorophyll must also be associated with an increase in the quantity of enzymes and coenzymes necessary for reduction of the products of photorespiration (Salisburg \& Rosss 1969). The pathway of chlorophyll synthesis is thought to be photoreduction of protochlorophyllide to chlorophyllide followed by phytol esterification to form chlorophyll-a. The phytol esterification of chlorophyllide-a to chlorophyll-a is catalysed by the enzyme cholorophyllase (Devlin, 1986). It is suggested that the chlorophyll-b is formed from chlorophyllide-a or chlorophyll a (Bogorad, 1967). The stimulation of different pigment contents of leaves of Cowpea by IAA treatments might be thought of as stimulation of chlorophyllase enzyme activity by these treatments on the precursor molecule of chlorophyll pigment.

\section{Moisture content of seeds}

The moisture content in the seeds is decreased by all IAA treatments (Table III). The highest moisture content of seeds, $10 \%$ was recorded from plant treated with distilled water. The decreases were 14.7, 17.7, 26.2 and 19.7\% due to 20, 40, 60,80 ppm IAA treatments respectively in comparison to control. Due to the different treatments variations in moisture content were significant. The percentage decrease over the control ranged from -26.22 to -14.65 . Change in moisture content is one of the early symptoms of hormone action on plants (Wort 1951; Freiberg and Clark 1952). Growth regulators other than IAA also have effects on moisture content of seeds. Haque (2002) reported that moisture content of maize grain was found to decrease following 2, 4-D (2, 4dichlorophenoxy acetic acid) treatments. The decrease in moisture content is something quite significant. The storage potential of a grain depends upon its moisture content. The less amount of moisture contents (up to specific limit) is more suitable for storage. 
Table III. Effect of different concentration of IAA on quality of seed content of Cowpea (results are expressed in \%)

\begin{tabular}{c|c|c|c|c|c|c|c|c}
\hline Treatments & Moisture & Ash & Crude fiber & Colorie & Protein & Fat & Carbohydrate & NFE \\
\hline $\mathrm{T}_{0}$ & $10.0 \mathrm{a}$ & $3.91 \mathrm{a}$ & 4.40 & $329.5 \mathrm{c}$ & $17.9 \mathrm{~b}$ & $0.58 \mathrm{~b}$ & 63.2 & $67.6 \mathrm{a}$ \\
$\mathrm{T}_{1}$ & $8.56 \mathrm{~b}$ & $3.91 \mathrm{a}$ & 4.68 & $337.2 \mathrm{~b}$ & $21.8 \mathrm{a}$ & $0.77 \mathrm{a}$ & 59.9 & $64.6 \mathrm{~b}$ \\
& $(-14.6)$ & $(0)$ & $(6.36)$ & $(2.34)$ & $(21.6)$ & $(32.7)$ & $(-5.16)$ & $(-4.42)$ \\
$\mathrm{T}_{2}$ & $8.26 \mathrm{bc}$ & $3.95 \mathrm{a}$ & 4.73 & $338.7 \mathrm{ab}$ & $22.0 \mathrm{a}$ & $0.87 \mathrm{a}$ & 60.0 & $64.9 \mathrm{~b}$ \\
& $(-17.6)$ & $(1.02)$ & $(7.50)$ & $(2.80)$ & $(23.2)$ & $(49.6)$ & $(-4.98)$ & $(-3.99)$ \\
$\mathrm{T}_{3}$ & $7.40 \mathrm{c}$ & $4.16 \mathrm{a}$ & 4.55 & $339.7 \mathrm{a}$ & $22.3 \mathrm{a}$ & $0.84 \mathrm{a}$ & 60.8 & $65.3 \mathrm{~b}$ \\
& $(-26.2)$ & $(6.39)$ & $(3.41)$ & $(3.10)$ & $(24.7)$ & $(44.6)$ & $(-3.83)$ & $(-3.39)$ \\
$\mathrm{T}_{4}$ & $8.05 \mathrm{bc}$ & $4.17 \mathrm{a}$ & 4.51 & $337.2 \mathrm{~b}$ & $22.8 \mathrm{a}$ & $0.83 \mathrm{a}$ & 59.7 & $64.2 \mathrm{~b}$ \\
& $(-19.7)$ & $(6.65)$ & $(2.50)$ & $(2.34)$ & $(27.4)$ & $(43.7)$ & $(-5.57)$ & $(-5.06)$ \\
$\mathrm{ANOVA}$ & $\mathrm{S}$ & $\mathrm{NS}$ & $\mathrm{NS}$ & $\mathrm{NS}$ & $\mathrm{S}$ & $\mathrm{NS}$ & $\mathrm{NS}$ & $\mathrm{S}$ \\
$\mathrm{CV}(\%)$ & 5.84 & 11.26 & 18.29 & $0.3 \%$ & 2.52 & 50.6 & 12.7 & 1.34 \\
LSD (5\%) & 1.12 & 1.29 & 2.29 & 2.75 & 1.49 & 1.99 & 15.0 & 1.64 \\
\hline
\end{tabular}

S for Significant; NS for non-significant; Average was taken over the values of 4 replicates.

Values within parentheses indicate percentage of change relative to the control $\left(\mathrm{T}_{0}\right)$.

Means in a column followed by the same letter do not differ significantly at $1 \%$ and $5 \%$ level.

\section{Ash content of seeds}

It is found that the ash content of Cowpea seed increased due to all the treatments except $\mathrm{T}_{1}$ (Table III). The increase was $6.7 \%$ due to $\mathrm{T}_{4}$ treatment ( $80 \mathrm{ppm}$ IAA) and other increases were $1 \%$ and $6.4 \%$ following $\mathrm{T}_{2}$ and $\mathrm{T}_{3}$ respectively over the control. But the effect of $\mathrm{T}_{1}$ treatment was not different from that of the control. Growth regulator other than IAA also has effect on ash content of seeds. Haque (2002) reported that ash content of maize grains decreased due to 2, 4-D (2, 4dichlorophenoxy acetic acid) treatments.

\section{Crude fiber content of seeds}

Crude fiber content of seeds did not significantly vary among different treatments but the highest crude fiber content of seeds $4.7 \%$ was recorded from the seeds of plants with treated $40 \mathrm{ppm} 1 \mathrm{AA}$ and it was $7.5 \%$ higher over that of the control (Table III). The lowest crude fiber content $4.4 \%$ was obtained from the seeds of plant treated with distilled water. The percentage increase over the control ranged from 2.5 to 7.5 .

\section{Calorie content of seeds}

The highest calorie content of seeds $339.7 \%$ was recorded from the seeds of the plant treated with 60 ppm IAA and it was $3.1 \%$ higher in comparison to control (Table III).
Similar results were found following 2, 4-D treatments by Haque (2002) on maize grains. The increases were 2.3, 2.8 and $2.3 \%$ due to 20,40 and 80 ppm IAA respectively in comparison to control. The lowest calorie of seeds $329.5 \%$ was recorded for control. The percentage of increase over the control ranged from 2.3 to 3.1 . The variations were significant due to different treatments of IAA.

\section{Protein content of seeds}

In the present investigation, it is found that the protein content of seeds increase with all the treatments. The highest protein content $22.8 \%$ was recorded from the plants treated with 80 ppm IAA ( $\mathrm{T}_{4}$ treatment) and it was $27.4 \%$ higher over that of the control (Table III). The other increases were $21.6,23.2$, and $24.7 \%$ due to $\mathrm{T}_{1}, \mathrm{~T}_{2}$, and $\mathrm{T}_{3}$ treatments respectively in comparison to control. Among the growth regulator treatments, variations were significant. The percentage increases over the control ranged from 21.6 to 27.4. The protein content of wheat grain was also increased by NAA (Naphthalene acetic acid) treatment (Shorokhova 1984; Biswas and Mondal 1988).

\section{Fat content of seeds}

The fat content of seeds increased following all treatments. The highest fat content of seeds $0.87 \%$ was recorded from 
the seeds of the plants treated with $\mathrm{T}_{2}$ treatment. At other treatments the fat content was gradually decreased with increasing concentration of IAA compared to $T_{2}$ treatment. The lowest fat content of seeds 0.58 was recorded from the control (Table III).

\section{Carbohydrate content of seeds}

Carbohydrate content and Nitrogen free extract of seeds were decreased with the increasing concentration of IAA. The highest carbohydrate content of seeds $63.2 \%$ was recorded from the seeds of the plants treated with distilled water. At the treatment of 80 ppm IAA the lowest carbohydrate content of seeds was $59.7 \%$. The decreases were -5.2 , $-5.0,-3.8,-5.6 \%$ over the control following $\mathrm{T}_{1}, \mathrm{~T}_{2}, \mathrm{~T}_{3}$ and $\mathrm{T}_{4}$ treatments respectively (Table III). Due to different treatments of IAA variations of carbohydrate content were insignificant.

\section{Conclusion}

From this study it can be concluded that different biochemical parameters responded differently following IAA treatments. Chlorophyll a, b contents were significantly influenced by different IAA treatments. Highest protein content $(22.8 \%)$ and ash content $(4.2 \%)$ were recorded from the seeds of the plants treated with 80 ppm IAA. Highest carbohydrate content $(60.8 \%)$ and calorie content were recorded from the seeds of the plants treated with $60 \mathrm{ppm}$ IAA. It was found that the moisture content decreased due to all treatments. Fat, crude fiber and NFE content of seeds also found to be varied with different treatments. The results of the present work also indicate that an appropriate concentration of IAA can be fruitfully utilized to produce better quality of seeds of Cowpea plants.

\section{References}

Ali B., Hayat H., Hasan S. A. and Ahmed A. (2008). A comparative effect of IAA and 4-Cl-IAA on growth, nodulation and nitrogen fixation in Vigna radiate $\mathrm{L}$. Wilczek. Acta Physiol. Plant., 30: 35-41.

Association of Official Agricultural Chemists (1985). Protocol for analytical methods, Gaithersburg, Maryland, USA.

Biswas A. K. and Mandol S. K. (1988). Manipulation of senescence, source-sink relationship and yield by growth regulating chemicals. Indian J. plant physiol., 31(2): 152-157.

Bogorad L. (1967). The organisation and development of chloroplasts. In J.M. Aken (ed.), Molecular organization and biological function. (Academic press, New York) pp 89.

Davies P. J. (2004). The plant hormones: Their nature, occurrence and functions. In: Davies PJ (ed.) Plant hormones, physiology, biochemistry and molecular biology. 2nd edn. (Kluwer, Dordrecht) pp1-12.

Devlin R. M. (1986). Plant physiology. 4th ed. (Enst West press Pvt. Ltd., India).

Freiberg S. R. and Clark H. B. (1952). Effect of 0, 2, 4Dichloro phenoxy acetic acid upon the nitrogen metabolism and water relations of soybean plants treated with 2, 4-Dicholorophenoxy acetic acid. Plant physio., 30: 39 - 46 .

Gomez K. A. and Gomez A. A. (1984). Statistical procedures for agricultural research. 2nd edn. (John Wiley, New York).

Gowda C. L. L. and Kaul A. K. (1982). Pulses in Bangladesh, Bangladesh Agricultural Research Institute and FAO, Dhaka, Bangladesh.

Haque Z. (2002). Effect of 2, 4-dichlorophenoxy acetic acid (2, 4-D) on growth, physiological \& biochemical responses and yield attributes of maize (Zea mays L. var. KHOI) M.Sc. Thesis, Jahangirnagar University, Dhaka, Bangladesh.

Kharkwal M. C., Jain H. K. and Sharma B. (1986). Induced mutations for improvement of chickpea, lentil pea and Cowpea. proc. workshop on improvement of grain legume production using induced mutation, IAEA / FAO, Vienna, Austria.

Macdonald H. (1997). Auxin perception and signal transduction. Physiol Plant, 100: 423-430.

Machlalan S. and Zalic S. (1963). Plastid structure, chlorophyll concentration and free amino acid composition of a chlorophyll mutant of barley. Con. J. Bot. 41:10531062. 
Mckinney G. (1940). Criteria for purity of chlorophyll preparation. J. Biol., 132: 91-107.

Rachie K. O. (1985). Cowpea Research, production and utilization. A Wiley Inter Science publication. Introduction. pp. xi-xxiii.

Salisbury F. B. and Ross C. (1969). Plant Physiology. (Words worth. pub. company. Inc. Califorinia, USA) pp 204.

Sentelhas P. C., Caetano J. R. G. and Teixeria N. T. (1987). The effect of IAA and of foliar nitrogen on wheat CV IAC-17 crop. Faculdade de Agronomiae zootecnia Monoel carolos Goncalives, Espirito Sando do pinhal, Brazil, Ecossistema 12 : 123 - 128.

Shobha J., Ashwani K., Johari S. and Kumar A. (1994). Influence of growth regulators on biomass and biocrude yield of Euphorbia antisyphilitica. Department of Botany, University of Rajasthan, Jaipur 302 004, India. Journal of physiological Research, 7(1): 65-68.

Shorokhova A. I. (1984). Effect of camposan (ethaphone) on growth development and yield of barley $\mathrm{cv}$. Karshefimskil, 95. 39: 94-98.
Subramanian V. K. and Janardhanan K. (1992). Effect of cytozyme on seed germination, early seedling growth and chloroplast pigments contents in certain pulse crops. Department of Botany, Bharathiar University, Coimbatore, Tamil Nadu, India. Madras Agricultural Journal, 79(1): 9-11.

Tadzhiryan O. K. (1990). Effect of $\mathrm{GA}_{3}$ on biochemical characteristics of the grain in wheat in the $\mathrm{m}$. and $\mathrm{m}^{2}$, Biologicahoskii -3- Journal - Armehii, 43(1): 77-79.

Tomar V. P. S., Singh G. D. and Keshwa G. L. (1991). Effect of plant growth chemicals on morpho-physiological characters of late sown wheat. Indian J. Agron., 36(1): 7- 11 .

Voronova N. L. and Kozyakov V. I. (1983). Effect of growth regulators on spring wheat yield, sibirskil vestnik sel's Kokhozy aistivenno Nauki. Field crops Abst. 1985, 38(4) : 160 - 161

Wort D. J. (1951). Effect of non-lethal concentrations of 2, 4, - D on buck wheat. plant physiol., 26 : 50 - 58.

Received : May 07, 2009;

Accepted : March 25, 2010 